\title{
Pengaruh Model Pembelajaran Thinking Aloud Pair Problem Solving (TAPPS) Terhadap Kemampuan Berpikir Kritis Matematis Siswa Berbantuan Kartu Domino
}

\author{
Osey Putri Salehha ${ }^{1}$, Siti Khaulah ${ }^{2}$, Nurhayati ${ }^{3}$ \\ 1,2,3 Program Studi Pendidikan Matematika, Fakultas Keguruan dan Ilmu Pendidikan, Universitas Almuslim \\ Jl. Almuslim Matangglumpangdua Peusangan Kabupaten Bireuen, Indonesia \\ osey.putri1999@gmail.com
}

\begin{abstract}
The low critical thinking ability of students in lessons is one of the causes of students' difficulties in understanding and solving problems within the limits of algebraic function material. Therefore, critical thinking skills are very important for students to have. This study aims to determine the effect of the Thinking Aloud Pair Problem Solving (TAPPS) learning model on students' critical thinking skills assisted by domino cards better than conventional learning on algebraic material in class XI SMA Negeri 2 Bireuen. The approach taken is a quantitative approach with a quasi-experimental type of research. The research design is the Nonequivalent Control Group Design. The population in this study were all students of class XI SMA Negeri 2 Bireuen which consisted of 9 classes, while the samples were class XI MIA 1 and class XI MIA 2. Samples were taken using purposive sampling technique. Results Based on data analysis using the independent sample $t$-test, the Sig value was obtained. (2-tailed) that is equal to 0.000 . This shows that the value of Sig. (2-tailed) is less than 0.05 , then $\mathrm{H} 0$ is rejected, meaning that the effect of the Thinking Aloud Pair Problem Solving (TAPPS) learning model on the critical thinking skills of domino card students is better than conventional learning on the material of limiting algebraic functions in class XI SMA Negeri 2 Bireuen.
\end{abstract}

Keywords: TAPPS, Critical Thinking Skills, Dominoes Cards

\begin{abstract}
Abstrak
Rendahnya kemampuan berpikir kritis siswa pada pelajaran matematika merupakan salah satu penyebab kesulitan siswa dalam memahami dan menyelesaikan permasalahan dalam materi limit fungsi aljabar. Oleh karena itu, kemampuan berpikir kritis sangat penting untuk dimiliki oleh siswa. Penelitian ini bertujuan untuk mengetahui pengaruh model pembelajaran Thinking Aloud Pair Problem Solving (TAPPS) terhadap kemampuan berpikir kritis matematis siswa berbantuan kartu domino lebih baik daripada pembelajaran konvensional pada materi limit fungsi aljabar di kelas XI SMA Negeri 2 Bireuen. Pendekatan yang dilakukan adalah pendekatan kuantitatif dengan jenis penelitian quasi experimental. Desain penelitian yaitu Nonequivalent Control Group Design. Populasi dalam penelitian ini adalah seluruh siswa kelas XI SMA Negeri 2 Bireuen yang terdiri dari 9 kelas, sedangkan yang menjadi sampel yaitu kelas XI MIA 1 dan kelas XI MIA 2. Sampel diambil dengan menggunakan teknik purposive sampling. Berdasarkan hasil analisis data data menggunakan uji independent sample t-test maka diperoleh nilai Sig. (2-tailed) yaitu sebesar 0.000. Hal ini menunjukkan bahwa nilai Sig. (2-tailed) kurang dari 0.05 maka $\mathrm{H}_{0}$ ditolak, artinya pengaruh model pembelajaran Thinking Aloud Pair Problem Solving (TAPPS) terhadap kemampuan berpikir kritis matematis siswa berbantuan kartu domino lebih baik daripada pembelajaran konvensional pada materi limit fungsi aljabar di kelas XI SMA Negeri 2 Bireuen.

Kata kunci: TAPPS, Kemampuan Berpikir Kritis Matematis, Kartu Domino
\end{abstract}

Copyright (c) 2021 Osey Putri Salehha, Siti Khaulah, Nurhayati

$\square$ Corresponding author: Nurhayati

Email Address: nurhayati.nur@gmail.com (Jl. Almuslim Matangglumpang dua Peusangan, Bireuen)

Received 28 August 2021, Accepted 22 December 2021, Published 28 December 2021

\section{PENDAHULUAN}

Pendidikan adalah salah satu sektor penting dalam pembangunan nasional yang berfungsi untuk meningkatkan kualitas hidup manusia. Pendidikan juga merupakan suatu usaha dalam mencerdaskan kehidupan bangsa. Hal ini tertuang dalam isi pembukaan UUD 1945 pada alinea IV yang menegaskan bahwa salah satu tujuan dari bangsa Indonesia adalah mencerdaskan kehidupan bangsa. Oleh sebab 
itu, pendidikan dianggap sebagai hal yang sangat penting dan wajib bagi siapapun, sehingga ada banyak ilmu pengetahuan yang harus dikuasai dalam pendidikan salah satunya adalah matematika ( $\mathrm{N}$ Nurhayati \& Novianti, 2020).

Matematika merupakan bidang ilmu yang menduduki peranan penting dalam dunia pendidikan ) (Jumaisyaroh et al., 2014; Widiyastuti, et al., 2014; Nisak \& Hadi, 2015; Pratama et al., 2018; Octariani \& Panjaitan, 2020; Nurhayati, 2020; Husnidar, 2020; Robiah, 2020; Nurhayati et al., 2021). Hal ini telihat dari hampir semua ilmu pengetahuan ada kaitannya dengan matematika bahkan setiap aktivitas yang dilakukan selalu membutuhkan matematika sebagai medianya. Selain itu, menurut Salehha \& Nurhayati, 2021 matematika juga merupakan salah satu ilmu pengetahuan yang dapat menumbuhkan berbagai kemampuan. Kemampuan-kemmapuan yang dimaksud adalah kemampuan berpikir kritis, kreatif, logis dan sistematis. Meskipun dianggap mempunyai peran yang sangat penting, tetapi masih banyak siswa yang tidak menyukai matematika karena menganggap pelajaran matematika adalah pelajaran yang sulit (Ulfa et al., 2018; Octariani \& Panjaitan, 2020; Rahmasari et al., 2021; Razi, 2021). Salah satu faktor yang menyebabkan siswa menganggap matematika sulit untuk dipelajari adalah karena kurangnya kemampuan siswa dalam berpikir kritis (Novianti \& Khaulah, 2020).

Kemampuan berpikir kritis merupakan salah satu kemampuan siswa yang dibutuhkan dalam kompetisi masa depan. Menurut Umam (2018) berpikir kritis dalam pembelajaran bertujuan mengarahkan siswa untuk memiliki cara berpikir yang terstruktur dan cerdas dalam mengorganisasikan antar konsep untuk memecahkan masalah. Menurut Nisak \& Hadi (2015) berpikir kritis merupakan salah satu jenis berpikir yang konvergen, yaitu jenis berpikir yang menuju ke satu titik. Selanjutnya menurut Lisa (2018) kemampuan berpikir kritis adalah suatu proses berpikir yang bertujuan untuk membuat keputusan-keputusan yang masuk akal mengenai sesuatu yang dapat di yakini kebenarannya. Oleh karena itu, dapat disimpulkan bahwa berpikir kritis dan matematika merupakan dua hal yang tidak bisa dipisahkan, karena materi yang ada pada matematika dapat dipahami melalui kemampuan berpikir kritis dan kemampuan berpikir kritis dilatih melalui proses yang ada dalam pembelajaran matematika. Namun pada kenyataannya kemampuan berpikir kritis yang dimiliki siswa pada pembelajaran matematika masih tergolong rendah.

Hal tersebut peneliti dapatkan pada saat melakukan wawancara dengan guru bidang studi matematika yang bernama Ibu Dra. Adna di SMA Negeri 2 Bireuen. Peneliti mendapatkan informasi bahwa siswa kelas XI SMA Negeri 2 Bireuen mengalami kesulitan pada materi limit fungsi aljabar. Kesulitan yang dialami siswa dalam hal ini yaitu siswa belum memahami secara tuntas sifat-sifat, konsep-konsep, dan syarat-syarat yang berlaku dalam materi limit fungsi aljabar, akibatnya siswa sering menyingkat proses penyelesaian dengan mensubstitusi langsung soal pada materi limit fungsi aljabar. Sejalan dengan pendapat Dewi et al. (2020) yang mengatakan bahwa pada materi limit fungsi aljabar siswa kesulitan dalam memahami rumus dan teorema limit, siswa juga dituntut untuk mampu 
menguasai prasyarat lainnya seperti konsep pemfaktoran, merasionalkan bentuk akar dan lain sebagainya.

Selain itu, penyebab lain dari rendahnya kemampuan berpikir kritis siswa adalah saat proses belajar mengajar guru jarang menggunakan model atau media pembelajaran. Guru nyaman dengan cara mengajar menggunakan metode ceramah dan ekspositori, yang pembelajarannya berpusat pada guru, sedangkan siswa kebanyakan mendengar, menerima, mencatat, menghafal dan belajar sesuai kecepatan guru (Zulyadaini, 2016). Pembelajaran dengan metode ceramah dan ekspositori ini merupakan pembelajaran satu arah yang membuat siswa tidak aktif dan cenderung merasa bosan. Oleh karena itu, seorang guru harus pintar dalam membangun suasana belajar dalam proses belajar mengajar didalam kelas (Nurhayati, 2019).

Berdasarkan hal di atas, maka guru perlu memilih suatu model pembelajaran matematika yang dapat memfasilitasi siswa dalam membentuk kemampuan berpikir kritis matematis. Salah satu adalah model pembelajaran yang bisa dipilih adalah Thinking Aloud Pair Problem Solving (TAPPS). Model pembelajaran Thinking Aloud Pair Problem Solving (TAPPS) adalah model pembelajaran secara berpasangan yang diperkenalkan oleh Claparade. Model pembelajaran Thinking Aloud Pair Problem Solving (TAPPS) adalah model pembelajaran yang melibatkan siswa bekerjasama dalam suatu kelompok dimana satu orang berperan sebagai problem solver (pemecah masalah) dan pasangannya berperan sebagai listener (pendengar).

Menurut Maula et al. (2014) model pembelajaran Thinking Aloud Pair Problem Solving (TAPPS) adalah model pembelajaran yang lebih menekankan kepada kemampuan penyelesaian masalah. Adapun menurut Setianingrum \& Novitasari (2015) model pembelajaran Thinking Aloud Pair Problem Solving ini lebih menekankan kepada siswa untuk berpikir secara keras dan logis. Kedua pendapat tersebut di perkuat oleh Astutik \& Edi (2018) sehingga model pembelajaran Thinking Aloud Pair Problem Solving (TAPPS) adalah model pembelajaran yang lebih menekankan pada kemampuan pemecahan masalah dimana siswa secara berpasangan harus berfikir logis dalam menyelesaikan masalah. Berdasarkan pendapat tersebut, maka dapat disimpulkan bahwa bahwa model pembelajaran Thinking Aloud Pair Problem Solving (TAPPS) adalah model pembelajaran yang menekankan kepada siswa kemampuan berpikir yang masuk akal agar dapat menyelesaikan suatu masalah. Oleh karena itu, diharapkan model pembelajaran ini dapat melatih siswa dalam kemampuan berpikir kritis matematis.

Selain model pembelajaran, siswa juga membutuhkan suatu media pembelajaran yang dapat meningkatkan kemampuan berpikir kritis dan dapat menciptakan suasana belajar yang aktif. Menurut Sutiarso et al. (2018) media pembelajaran adalah alat fisik yang dapat menyajikan dan menyampaikan pesan, serta merangsang siswa untuk belajar. Media yang digunakan dalam proses pembelajaran harus tepat dan sesuai dengan materi serta tujuan pembelajaran (Prihanto \& Yunianta, 2018). Khususnya pada pelajaran matematika, media adalah hal yang sangat dibutuhkan. Siswa cenderung merasa bosan dengan sistem belajar mengajar yang hanya menggunakan papan tulis dan buku sebagai media 
pembelajaran. Pentingnya media pembelajaran, menuntut seorang guru untuk mampu menggunakan media yang menarik agar terciptanya suasana belajar mengajar yang menyenangkan (Nengsih \& Rochmawati, 2014). Ketersediaan media pembelajaran matematika, membuat siswa tidak hanya belajar dengan mendengar dan mencatat, tetapi siswa juga lebih aktif dalam berpikir dan termotivasi dalam belajar (Handhika, 2012).

Salah satu media pembelajaran yang dapat menarik minat siswa agar aktif dalam pembelajaran matematika adalah kartu domino. Hal ini diperkuat oleh Larasati \& Poedjiastoeti (2016) yang mengatakan bahwa kartu domino adalah media seperti permainan yang memiliki kelebihan untuk membuat siswa terlibat aktif dan semangat dalam belajar, sehingga proses belajar mengajar tidak monoton. Media kartu domino juga membantu siswa dalam memahami materi, meningkatkan hasil belajar, dan dapat merangsang keaktifan serta pemikiran siswa dalam kegiatan belajar (Rahman \& Amalia, 2019). Penggunaan media pembelajaran kartu domino dipadukan dengan model pembelajaran Thinking Aloud Pair Problem Solving (TAPPS) diharapkan dapat membantu siswa meningkatkan kemampuan berpikir kritis dalam pelajaran matematika.

Beberapa penelitian yang telah dilakukan dengan menggunakan model pembelajaran Thinking Aloud Pair Problem Solving (TAPPS) terhadap kemampuan berpikir kritis siswa, yaitu penelitian dari Meidawati (2016) yang menyatakan bahwa "kemampuan berpikir kritis siswa yang diajarkan dengan menggunakan model pembelajaran pembelajaran Thinking Aloud Pair Problem Solving (TAPPS) lebih tinggi dari pada model pembelajaran langsung". Selanjutnya penelitian dari Rahmawati et al. (2019) yang menunjukkan bahwa "nilai rata-rata kemampuan berpikir kritis siswa dengan model pembelajaran Thinking Aloud Pair Problem Solving (TAPPS) lebih tinggi daripada model pembelajaran konvensional di kelas VIII SMP Negeri 7 Tarakan".

Berdasarkan uraian di atas, belum ada penelitian tentang pengaruh model pembelajaran Thinking Aloud Pair Problem Solving (TAPPS) terhadap kemampuan berpikir kritis matematis siswa berbantuan kartu domino pada materi limit fungsi aljabar. Oleh karena itu, tujuan dari penelitian ini adalah untuk mengetahui pengaruh model pembelajaran Thinking Aloud Pair Problem Solving (TAPPS) terhadap kemampuan berpikir kritis matematis siswa berbantuan kartu domino lebih baik daripada pembelajaran konvensional pada materi limit fungsi aljabar di kelas XI SMA Negeri 2 Bireuen.

\section{METODE}

Penelitian ini dilakukan dengan menggunakan pendekatan kuantitatif dan jenis penelitian eksperimen semu (quasi experimental). Desian penelitian yang tepat dilaksanakan dalam penelitian ini yaitu Nonequivalent Control Group Design. Adapun rancangan penelitian Nonequivalent Control Group Design sebagai berikut (Sugiyono, 2019):

Tabel 1. Rancangan Penelitian

\begin{tabular}{|c|c|c|c|}
\hline Kelas & Pretest & Treatment & Posttest \\
\hline Eksperimen & $\mathrm{O}_{1}$ & $\mathrm{X}$ & $\mathrm{O}_{2}$ \\
\hline
\end{tabular}


Keterangan:

\begin{tabular}{|l|l|l|l|}
\hline Kontrol & $\mathrm{O}_{3}$ & - & $\mathrm{O}_{3}$ \\
\hline
\end{tabular}

$\mathrm{O}_{1} \quad$ : Pre-test Kelas Eksperimen

$\mathrm{O}_{3} \quad$ : Pre-test Kelas Kontrol

$\mathrm{O}_{2} \quad$ : Post-test Kelas Eksperimen

$\mathrm{O}_{4} \quad$ : Post-test Kelas Kontrol

X : Perlakuan dengan menggunakan Model Pembelajaran Thinking Aloud Pair Problem Solving (TAPPS)

- $\quad$ : Tanpa Perlakuan (Pembelajaran Konvensional)

Siswa kelas XI SMA Negeri 2 Bireuen yang terdiri dari 9 kelas menjadi populasi dalam penelitian ini, sedangkan sampel terpilih adalah kelas XI MIA 1 sebagai kelas eksperimen dan XI MIA 2 sebagai kelas kontrol yang tiap kelas terdiri dari 32 orang. Pengambilan sampel menggunakan teknik purposive sampling. Instrumen yang digunakan dalam penelitian ini dan dianalisis adalah tes kemampuan berpikir kritis matematis. Intrumen tes dilaksanakan sebanyak dua kali yaitu tes awal (pretest) dan tes akhir (posttest) yang terdiri dari 5 soal bentuk uraian. Tes tersebut diberikan kepada kedua kelas yang menjadi sampel dalam penelitian.

Tes kemampuan berpikir kritis pada materi limit fungsi aljabar ini diberikan kepada siswa sebelum proses belajar mengajar menggunakan model pembelajaran. Hal ini dilakukan untuk mengetahui kemampuan awal siswa pada materi tersebut. Selanjutnya, diberikan perlakuan dengan model pembelajaran Thinking Aloud Pair Problem Solving (TAPPS) berbantuan kartu domino untuk kelas eksperimen dan dengan pembelajaran konvensional untuk kelas kontrol. Kartu domino yang dibagikan kepada kelas eksperimen diberikan sebanyak 2 kali dengan submateri limit yang berbeda. Setelah proses pembelajaran berakhir, siswa diberikan lagi tes sebagai hasil dari proses belajar mengajar. Kedua tes tersebut dijadikan data dalam penelitian ini. Kemudian, data yang diperoleh dianalisis dengan menggunakan bantuan SPSS versi 22.

Analisis kemampuan berpikir kritis matematis dianalisis dengan menggunakan uji statistik yang sesuai, yaitu uji normalitas, uji homogenitas, uji korelasi product moment dan uji hipotesis (Independent Sample T-Test). Pada uji korelasi product moment, data yang digunakan untuk memperoleh hubungan antara kedua variabel adalah data pretest dan posttest dari kelas yang menjadi sampel dalam penelitian ini. Adapun pelaksanaan pembelajaran dengan menggunakan pembelajaran Thinking Aloud Pair Problem Solving (TAPPS) berbantuan kartu domino pada materi limit fungsi aljabar, dijabarkan sebagai berikut:

1. Mula-mula guru menyajikan materi limit fungsi aljabar.

2. Guru memberikan beberapa contoh soal dan menjelaskannya.

3. Kemudian guru membagi siswa ke dalam beberapa kelompok, yang tiap kelompok terdiri dari 2 orang siswa. 
4. Kelompok dibagikan secara heterogen. Siswa menentukan sendiri siapa yang menjadi problem solver dan listener.

5. Guru kemudian membagikan kartu domino kepada setiap kelompok.

6. Tiap kelompok mendapatkan satu set kartu domino yang berjumlah 26 kartu, lalu kartu dikocok dan dibagikan habis kepada pemain.

7. Siswa yang mendapatkan kartu bertuliskan "Start" berhak meletakkan kartu pertama dan otomatis menjadi seorang listener.

8. Setelah kartu dikeluarkan, siswa lain menjadi problem solver dan harus mencari jawaban dari soal yang ada pada sisi kanan kartu bertuliskan "Start".

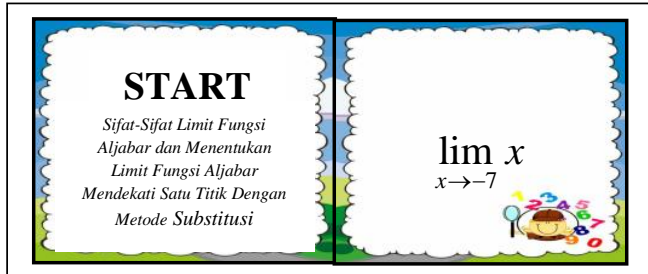

A

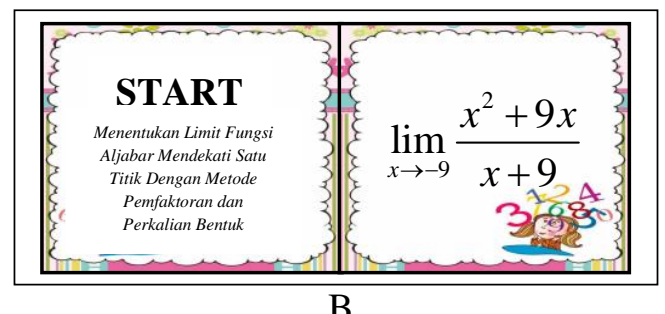

B

9. Kemudian, siswa yang berhasil mendapatkan jawaban pada kartu sebelumnya berhak meletakkan kartu tersebut disebelah kartu sebelumnya.
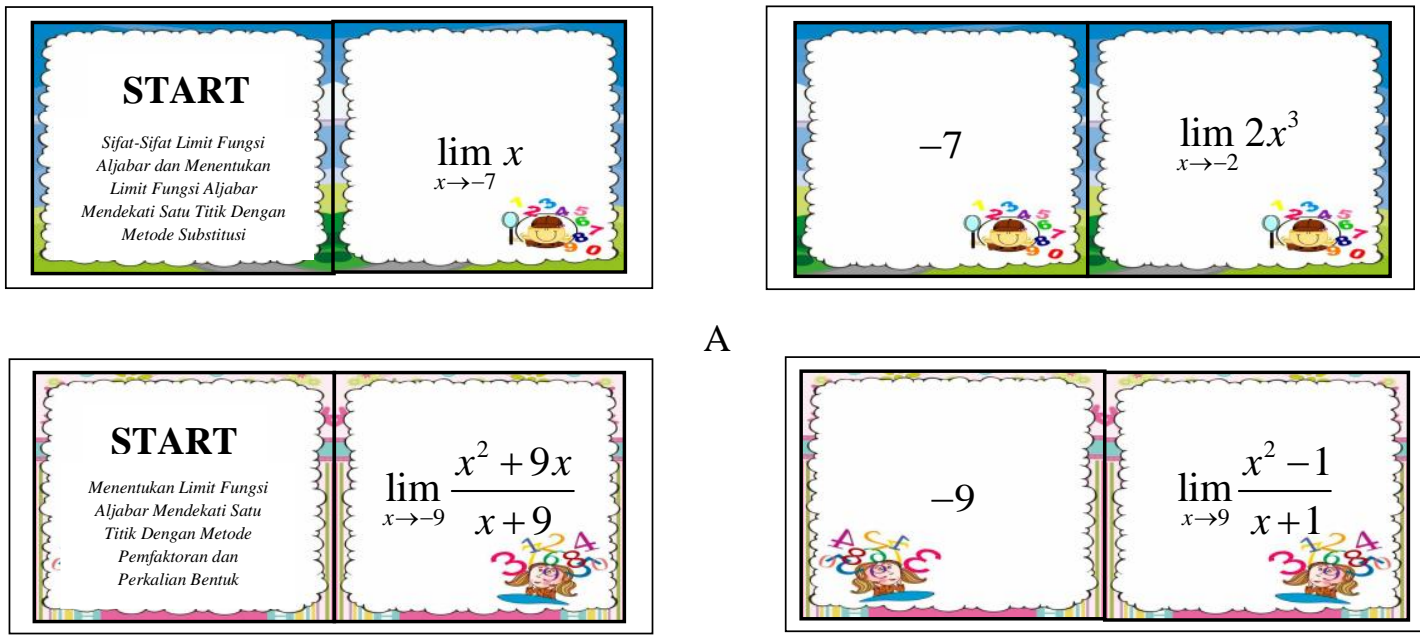

A

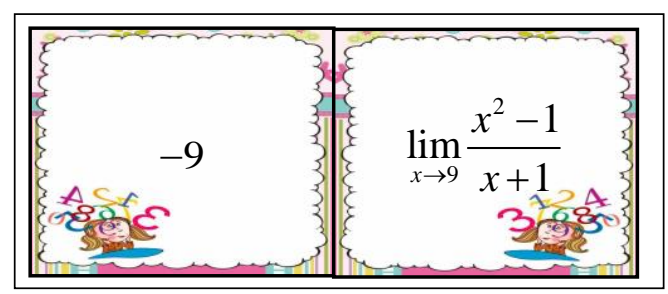

B

10. Kelompok yang pertama menyelesaikan permainan kartu domino dan benar memasangkan kartu domino dinyatakan sebagai pemenang, dan permainan berakhir. Permainan kartu domino berakhir ditandai dengan kartu yang bertuliskan kata "Finish".

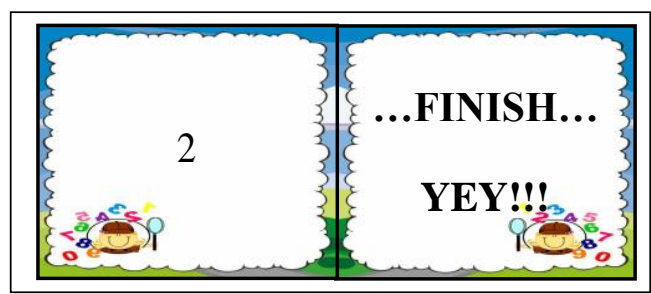

A

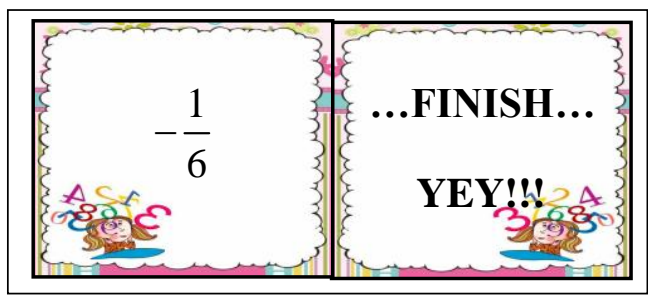

B 
Pengaruh Model Pembelajaran Thinking Aloud Pair Problem Solving (TAPPS) Terhadap Kemampuan Berpikir Kritis Matematis Siswa Berbantuan Kartu Domino, Osey Putri Salehha, Siti Khaulah, Nurhayati

Keterangan:

Gambar A. Kartu domino sub materi pertama

Gambar B. Kartu domino sub materi kedua

\section{HASIL DAN DISKUSI}

Tes kemampuan berpikir kritis matematis dilakukan sebanyak dua kali, yaitu tes awal (pretest) dan tes akhir (posttest). Hasil pretest diperoleh dari nilai siswa sebelum pembelajaran dengan menggunakan model pembelajara Thinking Aloud Pair Problem Solving (TAPPS) dan pembelajaran konvensional dilaksanakan. Selanjutnya, hasil posttest diperoleh dari nilai siswa setelah pembelajaran dengan menggunakan model pembelajaran Thinking Aloud Pair Problem Solving (TAPPS) dan pembelajaran konvensional dilaksanakan. Adapun data hasil pretest dan posttest kemampuan berpikir kritis siswa dapat dilihat pada Tabel 2 berikut.

Tabel 2. Data Hasil Pretest dan Posttest

\begin{tabular}{|l|c|c|c|c|}
\hline \multirow{2}{*}{ Statistik } & \multicolumn{2}{|c|}{ Kelas Eksperimen } & \multicolumn{2}{c|}{ Kelas Kontrol } \\
\cline { 2 - 5 } & Pretest & Posttest & Pretest & Posttest \\
\hline $\mathrm{N}$ & 32 & 32 & 32 & 32 \\
\hline Rentang & 12 & 10 & 9 & 11 \\
\hline Skor Minimal & 4 & 10 & 4 & 6 \\
\hline Skor Maksimal & 16 & 20 & 13 & 17 \\
\hline Mean & 9.88 & 14.56 & 8.53 & 11.75 \\
\hline Standar Deviasi & 3.250 & 2.994 & 2.627 & 2.640 \\
\hline Varian & 10.565 & 8.964 & 6.902 & 6.968 \\
\hline
\end{tabular}

Berdasarkan Tabel 2 menunjukkan bahwa skor minimal pretest kemampuan berpikir kritis di kelas eksperimen dan kontrol adalah 4. Skor maksimal pretest kemampuan berpikir kritis kelas eksperimen adalah 16 dan kelas kontrol adalah 13. Pada hasil posttest kemampuan berpikir kritis, skor minimal kelas eksperimen adalah 10 dan kelas kontrol adalah 6. Selanjutnya, skor maksimal posttest kemampuan berpikir kritis kelas eksperimen adalah 20 dan kelas kontrol adalah 17. Skor rata-rata pretest kemampuan berpikir kritis siswa untuk kelas eksperimen adalah 9.88 dan kelas kontrol adalah 8.53 .

Selanjutnya, skor rata-rata posttest kemampuan berpikir kritis siswa setelah proses pembelajaran di kelas eksperimen lebih tinggi dibandingkan dengan kelas kontrol. Skor rata-rata posttest nya adalah 14.56 dan 11.75 . Hal ini menunjukkan bahwa kemampuan berpikir kritits kelas eksperimen lebih tinggi dibandingkan dengan kelas kontrol. Selanjutnya, dilakukan uji normalitas untuk pretest dan posttest kedua kelas, hasil uji tersebut dapat dilihat pada Tabel 3 berikut.

Tabel 3. Uji Normalitas Pretest dan Posttest

\begin{tabular}{|c|c|c|c|c|}
\hline \multirow{2}{*}{ Kelas } & \multicolumn{3}{c|}{ Kolmogorov-Smirnov } \\
\cline { 3 - 5 } & Statistic & $\boldsymbol{d}$ f & Sig. \\
\hline \multirow{2}{*}{ Eksperimen } & Pretest & 0.135 & 32 & 0.144 \\
\cline { 2 - 5 } & Posttest & 0.129 & 32 & 0.188 \\
\hline Kontrol & Pretest & 0.149 & 32 & 0.067 \\
\hline
\end{tabular}




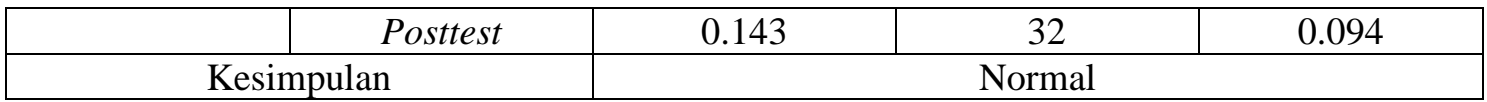

Berdasarkan Tabel 3 diketahui bahwa nilai Sig. pada pretest dan posttest kelas eksperimen masing-masing 0.144 dan 0.188 , sedangkan pretest dan posttest kelas kontrol maisng-masing 0.067 dan 0.094. Kedua kelas memiliki nilai Sig. pretest dan posttest yang lebih besar dari 0.05 sehingga dapat dikatakan bahwa kedua kelas tersebut berdistribusi normal. Selanjutnya, dilakukan uji homogenitas pretest dan posttest kedua kelas. Uji homogenitas ini dilakukan untuk menguji kesamaan dua variabel. Adapun hasil uji homogenitas pretest dan posttest dapat dilihat pada Tabel 4.

Tabel 4. Uji Homogenitas Pretest dan Posttest

\begin{tabular}{|c|c|c|}
\hline \multirow{2}{*}{ Statistik } & \multicolumn{2}{|c|}{ Data } \\
\cline { 2 - 3 } & Pretest & Posttest \\
\hline Levene Statistic & 1.570 & 0.542 \\
\hline$d f 1$ & 1 & 1 \\
\hline$d f 2$ & 62 & 62 \\
\hline Sig. & 0.215 & 0.464 \\
\hline Kesimpulan & \multicolumn{2}{|c|}{ Homogen } \\
\hline
\end{tabular}

Berdasarkan Tabel 4 dapat dilihat bahwa nilai Sig. dari data pretest sebesar 0.215 dan posttest sebesar 0.464. Nilai Sig. yang diperoleh dari data kemampuan berpikir kritis matematis tersebut menunjukkan nilai lebih besar dari 0.05 , sehingga dapat dikatakan bahwa data pretest dan posttest kemampuan berpikir kritis matematis dari kedua kelas adalah homogen. Selanjutnya, untuk mengetahui hubungan antar dua variabel dari setiap kelas yang menjadi sampel dalam penelitian ini dilakukan dengan mengunakan uji korelasi product moment. Variabel yang dimaksud adalah nilai siswa sebelum dan sesudah melaksanakan pembelajaran dengan perlakuan yang diterapkan pada setiap kelas. Keputusan mengenai derajat keeratan hubungan antar dua variabel dilihat pada bagian Pearson Correlation. Interpretasi pada uji korelasi product moment yaitu sangat rendah, rendah, sedang, kuat dan sangat kuat. Adapun hasil uji korelasi product moment dapat dilihat pada Tabel 5.

Tabel 5. Uji Korelasi Product Moment

\begin{tabular}{|c|c|c|c|c|c|}
\hline \multicolumn{2}{|c|}{ Kelas } & \multicolumn{2}{c|}{ Pretest } & \multicolumn{2}{c|}{ Posttest } \\
\cline { 3 - 6 } \multicolumn{2}{|c|}{} & $\begin{array}{c}\text { Pearson } \\
\text { Correltion }\end{array}$ & N & $\begin{array}{c}\text { Pearson } \\
\text { Correltion }\end{array}$ & N \\
\hline \multirow{2}{*}{ Eksperimen } & Pretest & 1 & 32 & 0.873 & 32 \\
\cline { 2 - 6 } & Posttest & 0.873 & 32 & 1 & 32 \\
\hline \multirow{2}{*}{ Kontrol } & Pretest & 1 & 32 & 0.745 & 32 \\
\cline { 2 - 6 } & Posttest & 0.745 & 32 & 1 & 32 \\
\hline
\end{tabular}

Berdasarkan Tabel 5 dapat dilihat bahwa hasil uji korelasi product moment kelas eksperimen menunjukkan bahwa nilai pada pearson correlation sebesar 0.843 yang memiliki interpretasi sangat kuat. Pada kelas kontrol nilai pearson correlation yang diperoleh sebesar 0.745 memiliki interpretasi kuat. Oleh karena itu, dapat disimpulkan bahwa hubungan antara nilai siswa sebelum dan sesudah melaksanakan pembelajaran pada kelas eksperimen lebih kuat dibandingkan dengan perlakuan pada 
kelas kontrol. Selanjutnya, untuk mengetahui apakah pengaruh model pembelajaran Thinking Aloud Pair Problem Solving (TAPPS) terhadap kemampuan berpikir kritis matematis siswa lebih baik daripada pembelajaran konvensional pada materi limit fungsi aljabar di kelas XI SMA Negeri 2 Bireuen, maka akan dianalisis menggunakan uji-t. Uji-t yang digunakan dalam penelitian ini adalah Independent Sample T-Test dengan Sig. 0.05. Adapun pengujian dilakukan berdasarkan hipotesis:

$H_{0}: \mu_{1}=\mu_{2}$ : Pengaruh model pembelajaran Thinking Aloud Pair Problem Solving (TAPPS) terhadap kemampuan berpikir kritis matematis siswa berbantuan kartu domino sama dengan pembelajaran konvensional pada materi limit fungsi aljabar di kelas XI SMA Negeri 2 Bireuen.

$H_{a}: \mu_{1}>\mu_{2}$ : Pengaruh model pembelajaran Thinking Aloud Pair Problem Solving (TAPPS) terhadap kemampuan berpikir kritis matematis siswa berbantuan kartu domino lebih baik daripada pembelajaran konvensional pada materi limit fungsi aljabar di kelas XI SMA Negeri 2 Bireuen.

Adapun kriteria pengujiannya adalah jika nilai Sig. (2-tailed) yang diperoleh lebih besar dari 0.05 maka $\mathrm{H}_{0}$ diterima dan jika nilai Sig. (2-tailed) yang diperoleh lebih kecil dari 0.05 maka $\mathrm{H}_{0}$ ditolak. Adapun hasil uji hipotesis dapat dilihat pada Tabel 6 berikut.

Tabel 6. Uji Hipotesis

\begin{tabular}{|c|c|c|c|c|c|c|c|}
\hline & \multicolumn{7}{|c|}{ t-test for Equality of Means } \\
\hline & \multirow[t]{2}{*}{$t$} & \multirow[t]{2}{*}{$d f$} & \multirow{2}{*}{$\begin{array}{l}\text { Sig. } \\
(2- \\
\text { tailed })\end{array}$} & \multirow[t]{2}{*}{$\begin{array}{c}\text { Mean } \\
\text { Difference }\end{array}$} & \multirow{2}{*}{$\begin{array}{c}\text { Std. } \\
\text { Error } \\
\text { Difference }\end{array}$} & \multicolumn{2}{|c|}{$\begin{array}{l}\text { 95\% Confidence } \\
\text { Interval of The } \\
\text { Difference }\end{array}$} \\
\hline & & & & & & Lower & Upper \\
\hline $\begin{array}{c}\text { Equal } \\
\text { variances } \\
\text { assumed }\end{array}$ & 3.986 & 62 & 0.000 & 2.813 & 0.706 & 1.402 & 4.223 \\
\hline $\begin{array}{c}\text { Equal } \\
\text { variances not } \\
\text { assumed }\end{array}$ & 3.986 & 61.042 & 0.000 & 2.813 & 0.706 & 1.402 & 4.223 \\
\hline Kesimpulan & & & & $\mathrm{H}_{0}$ dit & $\operatorname{lan} \mathrm{H}_{\mathrm{a}}$ dite & & \\
\hline
\end{tabular}

Berdasarkan Tabel 6 hasil analisis data yang dilakukan dengan menggunakan uji independent sample t-test diperoleh nilai Sig. (2-tailed) sebesar 0.000. Nilai yang dihasilkan tersebut menunjukkan nilai Sig. (2-tailed) lebih kecil dari 0.05 maka dapat disimpulkan bahwa $\mathrm{H}_{0}$ ditolak dan $\mathrm{H}_{\mathrm{a}}$ diterima, artinya pengaruh model pembelajaran Thinking Aloud Pair Problem Solving (TAPPS) terhadap kemampuan berpikir kritis matematis siswa lebih baik daripada pembelajaran konvensional pada materi limit fungsi aljabar di kelas XI SMA Negeri 2 Bireuen.

Hasil penelitian menunjukkan bahwa adanya pengaruh kemampuan berpikir kritis matematis siswa dengan menggunakan model pembelajaran Thinking Aloud Pair Problem Solving (TAPPS). Kemampuan berpikir kritis matematis siswa dengan menerapkan model pembelajaran Thinking Aloud 
Pair Problem Solving (TAPPS) lebih baik daripada pembelajaran konvensional. Hal ini dikarenakan, pada saat proses belajar mengajar dengan menggunakan model pembelajaran Thinking Aloud Pair Problem Solving (TAPPS) siswa terlibat aktif dalam pembelajaran dan lebih bertanggung jawab dalam menyelesaikan masalah yang telah diberikan. Penggunaan model pembelajaran Thinking Aloud Pair Problem Solving (TAPPS) tidak hanya untuk meningkatkan kemampuan siswa dalam berpikir kritis, tetapi dapat juga menambah wawasan siswa dalam memahami suatu materi dengan lebih baik.

\section{KESIMPULAN}

Berdasarkan hasil dan pembahasan yang telah dijabarkan, maka dapat disimpulkan bahwa pengaruh model pembelajaran Thinking Aloud Pair Problem Solving (TAPPS) terhadap kemampuan berpikir kritis matematis siswa lebih baik daripada pembelajaran konvensional pada materi limit fungsi aljabar di kelas XI SMA Negeri 2 Bireuen. Hasil tes pada kelas eksperimen juga menunjukkan peningkatan yang lebih tinggi dibandingkan dengan kelas kontrol. Hal ini dikarenakan pada saat proses belajar mengajar dengan menerapkan model pembelajaran Thinking Aloud Pair Problem Solving (TAPPS) siswa terlibat langsung dalam proses pembelajaran dan bertanggung jawab dalam menyelesaikan permasalahan yang diberikan.

Adapun saran dari penelitian ini diharapkan dapat dijadikan alternatif dalam proses pembelajaran matematika menggunakan model pembelajaran Thinking Aloud Pair Problem Solving (TAPPS) berbantuan kartu domino dengan mengkombinasikan pada materi-materi lain. Selanjutnya, untuk penelitian lebih lanjut disarankan untuk dapat melanjutkan penelitian pada pokok bahasan dan kemampuan matematis lainnya.

\section{UCAPAN TERIMA KASIH}

Terima kasih peneliti ucapkan kepada orang tua dan keluarga yang telah memberikan dukungan dalam melaksanakan penelitian. Peneliti juga mengucapkan terima kasih kepada kepala sekolah, guru-guru dan siswa kelas XI SMA Negeri 2 Bireuen yang telah berkontribusi dalam pelaksanaan penelitian. Terima kaish juga peneliti ucapkan kepada pembimbing saya yaitu Ibu Siti Khaulah, M.Pd dan Ibu Nurhayati, S.Pd., M.Si yang telah memberikan bimbingan serta arahan sehingga peneliti dapat menyelesaikan penelitian dan artikel ini.

\section{REFERENSI}

Astutik, M. A. D., \& Edi, S. (2018). Pengaruh Model Pembelajaran Think Aloud Pair Problem Solving (TAPPS) Terhadap Kemampuan Pemecahan Masalah Matematika Terhadap Kemampuan Pemecahan Masalah matematika. Didaktika, 25(1), 79-84. https://doi.org/http://dx.doi.org/10.30587/didaktika.v25i1.696

Dewi, S. D. A. S., Roza, Y., \& Maimunah, M. (2020). Faktor Penyebab Siswa tidak dapat Menyelesaikan Soal Materi Limit Fungsi Aljabar. Jurnal Penelitian Dan Pengkajian Ilmu 
Pendidikan: E-Saintika, 4(2), 134-150. https://doi.org/10.36312/e-saintika.v4i2.206

Handhika, J. (2012). Efektivitas media pembelajaran im3 ditinjau dari motivasi belajar. Jurnal Pendidikan IPA Indonesia, 1(2), 109-114. https://doi.org/10.15294/jpii.v1i2.2127

Husnidar, H. (2020). Meningkatkan Kemampuan Pemecahan Masalah Siswa Melalui Model Pembelajaran Glasser Pada Materi Bangun Ruang Sisi Datar Di SMP N 1 Samalanga. ASIMETRIS: Jurnal Pendidikan Matematika Dan Sains, 1(2), 57-63. https://doi.org/https://doi.org/10.51179/asimetris.v1i2.144

Jumaisyaroh, T., Napitupulu, E. E., \& Hasratuddin, H. (2014). Peningkatan Kemampuan Berpikir Kritis Matematis Dan Kemandirian Belajar Siswa Smp Melalui Pembelajaran Berbasis Masalah. Kreano, Jurnal Matematika Kreatif-Inovatif, 5(2), 157-169. https://doi.org/10.15294/kreano.v5i2.3325

Larasati, L. D., \& Poedjiastoeti, S. (2016). Pengembangan Permainan Kartu Domino Kimia Sebagai Media Pembelajaran Pada Materi Unsur Bagi Siswa SMALB Tunarungu. Journal of Chemical Education, 5(1), 115-119. https://jurnalmahasiswa.unesa.ac.id/index.php/journal-of-chemicaleducation/article/view/14456/13125

Lisa, L. (2018). Peningkatan Kemampuan Berpikir Kritis Matematik Siswa SMP Negeri Lhokseumawe Melalui Pendekatan Pembelajaran Matematika Realistik. Itqan, 9(1), 153-166.

Maula, N., Rochmad, R., \& Soedjoko, E. (2014). Keefektifan Pembelajaran Model Tapps Berbantuan Worksheet Terhadap Kemampuan Pemecahan Masalah Materi Lingkaran. Jurnal Pendidikan $\begin{array}{llllll}\text { Matematika Dan } & \text { Sains }\end{array}$ https://journal.uny.ac.id/index.php/jpms/article/view/3889

Meidawati, N. G. A. (2016). Pengaruh Model Pembelajaran Kooperatif Tipe Thinking Aloud Pair Problem Solving (TAPPS) Terhadap Kemampuan Berpikir Kritis Matematis Siswa Kelas VIII SMP Negeri 5 Gorontalo. In Universitas Negeri Gorontalo (Issue Skripsi).

Nengsih, R. F., \& Rochmawati, R. (2014). Pengembangan Kartu Domino Sebagai Media Pembelajaran Akuntansi Pada Materi Ayat Jurnal Penyesuaian. Jurnal Pendidikan Akuntansi, 2(2), 1-10. https://jurnalmahasiswa.unesa.ac.id/index.php/jpak/article/view/9140/9090

Nisak, S. K., \& Hadi, S. (2015). Analisis Proses Berpikir Kritis Siswa dalam Menyelesaikan Soal Peluang. Prosiding Seminar Nasional Pendidikan Matematika (Semnasdikta) IAIN Tulungagung, January 2015, 208-220.

Novianti, N., \& Khaulah, S. (2020). Penerapan Strategi Pembelajaran Numbered Head Together (NHT) Untuk Meningkatkan Kemampuan Berpikir Kritis Siswa Pada Materi Trigonometri Di Kelas X SMA Negeri 1 Kuala. JEMAS: Jurnal Edukasi Matematika Dan Sains, 1(1), 30-34. http://www.journal.umuslim.ac.id/index.php/jemas/article/view/50

Nurhayati, N., \& Novianti, N. (2020). PENGARUH SPSS TERHADAP HASIL BELAJAR PADA MATERI STATISTIKA DESKRIPTIF. AKSIOMA: Jurnal Program Studi Pendidikan Matematika, 9(1), 101-107. https://doi.org/https://doi.org/10.24127/ajpm.v9i1.2609. 
Nurhayati, N., Rofiroh, R., \& Riski, D. (2021). An Analysis Conceptual Understanding and Student's Learning Self-Reliance in the New Normal Era Assisted by Photomath on SLETV Material. Atlantik Press: Proceedings of the 1st International Conference on Mathematics and $\begin{array}{lll}\text { Mathematics } \quad \text { Education } & \text { 2020), }\end{array}$ https://doi.org/https://doi.org/10.2991/assehr.k.210508.058

Nurhayati, N. (2019). Pengaruh Strategi Pembelajaran Planet Questions Terhadap Prestasi Belajar Siswa Pada Materi Trigonometri Di Kelas X SMAN 1 Bireuen. Jurnal Pendidikan Almuslim, 7(1), 45-49. http://jfkip.umuslim.ac.id/index.php/jupa/article/view/423

Nurhayati, N. (2020). Pengaruh Peer Teaching Berbantuan Aplikasi SPSS Terhadap Kemampuan Penguasaan Konsep Pada Materi Statsitika. Gammath: Jurnal Ilmiah Program Studi Pendidikan Matematika, 5(2), 72-78. https://doi.org/10.32528/gammath.v5i2.3543

Octariani, D., \& Panjaitan, A. C. (2020). Penerapan Model Pembelajaran Team Games Tournament (TGT) Untuk Meningkatkan Motivasi dan Minat Belajar Matematika Siswa. ASIMETRIS: Jurnal Pendidikan Matematika Dan Sains, $\quad$ 1(2), 43-49. https://doi.org/https://doi.org/10.51179/asimetris.v1i2.142

Pratama, L. D., Lestari, W., \& Jailani, J. (2018). Implementasi Pendekatan Saintifik Melalui Problem Based Learning Terhadap Minat dan Prestasi Belajar Matematika. JMPM: Jurnal Matematika Dan Pendidikan Matematika, 3(1), 11-21. https://doi.org/10.26594/jmpm.v3i1.1051

Prihanto, D. A., \& Yunianta, T. N. H. (2018). Pengembangan Media Komik Matematikapada Materi Pecahan Untuk Siswa Kelas V Sekolah Dasar. MAJU, 5(1), 79-90. https://ejournal.stkipbbm.ac.id/index.php/mtk/article/view/137

Rahman, A. A., \& Amalia, Y. (2019). Development of Domino Card as Math Learning Media to train students' Conceptual understanding. Formatif: Jurnal Ilmiah Pendidikan MIPA, 9(2), 91-100. https://doi.org/10.30998/formatif.v9i2.3089

Rahmasari, D., Dadi, O., \& Suryani, D. R. (2021). Upaya Peningkatan Prestasi Belajar Matematika Menggunakan Pendekatan Problem Posing. ASIMETRIS: Jurnal Pendidikan Matematika Dan Sains, 2(1), 16-22. https://doi.org/https://doi.org/10.51179/asimetris.2.1.16-22

Rahmawati, Y., Hamid, H., \& Izzatin, M. (2019). Pengaruh Model Pembelajaran Kooperatif Tipe Tapps Terhadap Kemampuan Berpikir Kritis Matematis Ditinjau Dari Disposisi Matematis. Mathematic Education And Aplication Journal, 1(1), 73-84.

Razi, Z. (2021). Model Pembelajaran Kooperatif Tipe The Power Of Two Untuk Meningkatkan Self Efficacy Siswa Dalam Pembelajaran Matematika. ASIMETRIS: Jurnal Pendidikan Matematika Dan Sains, 2(1), 1-6. https://doi.org/https://doi.org/10.51179/asimetris.2.1.1-6

Robiah, S. S. (2020). Analisis Kesulitan Siswa Kelas XII dalam Menyelesaikan Soal Pada Materi Limit Fungsi. Jurnal Equation: Teori Dan Penelitian Pendidikan Matematika, 3(1), 65-75. https://ejournal.iainbengkulu.ac.id/index.php/equation/article/view/2655

Salehha, O. P., \& Nurhayati, N. (2021). Pengaruh Model Pembelajaran Time Token Terhadap 
Kemampuan Berpikir Kreatif Matematis Siswa. Musamus Jurnal of Mathematics Education, 3(2), 48-56. https://doi.org/https://doi.org/10.35724/mjme.v3i2.3593

Setianingrum, M. A., \& Novitasari, D. (2015). Pengaruh Model Pembelajaran Thinking Aloud Pair Problem Solving (Tapps) Terhadap Kemampuan Pemahaman Matematis Siswa. Fibonacci Jurnal Pendidikan Matematika Dan Matematika, 1(2), 59-70. https://doi.org/10.24853/fbc.1.2.59-70

Sugiyono. (2019). Metode Penelitian Kuantitatif, Kualitatif dan R\&D.

Sutiarso, S., Coesamin, M., \& Nurhanurawati. (2018). The effect of various media scaffolding on increasing understanding of students' geometry concepts. Journal on Mathematics Education, 9(1), 95-102. https://doi.org/10.22342/jme.9.1.4291.95-102

Ulfa, I. S. K., Trapsilasiwi, D., \& Yudianto, E. (2018). Profil Berpikir Kritis Siswa dalam Menyelesaikan Soal Fungsi Komposisi melalui Model Pembelajaran Kolaboratif. Jurnal Didaktik Matematika, 5(1), 40-53. https://doi.org/10.24815/jdm.v5i1.9972

Umam, K. (2018). Peningkatan Kemampuan Berpikir Kritis Matematis Siswa Melalui Pembelajaran Reciprocal Teaching. JPMI (Jurnal Pendidikan Matematika Indonesia), 3(2), 57-61. https://doi.org/10.26737/jpmi.v3i2.807

Widiyastuti, D., Elniati, S., \& Nasution, M. L. (2014). Penerapan Strategi Thinking Aloud Pair Problem Solving (TAPPS) Dalam Pembelajaran Matematika Kelas Viii Smpn 11 Padang. Jurnal $\begin{array}{llll}\text { Pendidikan } & \text { Matematika, 20-25. }\end{array}$ http://ejournal.unp.ac.id/students/index.php/pmat/article/view/1201

Zulyadaini, Z. (2016). Perbandingan Hasil Belajar Matematika Model Pembelajaran Kooperatif Tipe Coop-Coop Dengan Konvensional. Jurnal Ilmiah Universitas Batanghari, 16(1), 153-158. http://ji.unbari.ac.id/index.php/ilmiah/article/view/96. 